\title{
絹フィブロインと複合化した米粉のスポンジケーキ 調製とその特性
}

\author{
藤井恵子*・高橋貞幸*・木内瑠美子*

\begin{abstract}
Preparation and Properties of a Novel Sponge Cake by Combining Rice Flour with Silk Fibroin Protein
\end{abstract} \\ Keiko FuJi*, Sadayuki TaKahashi* and Rumiko KinOuCHI* \\ * Faculty of Education, Yamagata University, 1-4-12, Kojirakawa-machi, \\ Yamagata-shi, Yamagata 990-8560
}

\begin{abstract}
We developed a novel foam-containing food, that is made from rice flour combined with silk fibroin, without wheat flour. A silk fibroin was extracted from sericin-removed yarn in $35 \%$ calcium chloride at $98^{\circ} \mathrm{C}$ for $6 \mathrm{hrs}$. A foam-containing dough was prepared by mixing rice flour and the foam of dialyzed fibroin solution. The sponge cake made from rice flour and silk fibroin foam didn't expand well, and was lower specific volume than that made from wheat flour and egg white foam. Added silk fibroin suppressed the retrogradation of sponge cakes. In sensory evaluation, the sponge cake made from rice flour and the egg white/silk fibroin mixed foam was appreciated that its crumb was fine $(\mathrm{P}<0.01)$, moist $(\mathrm{P}<0.01)$ and palatable $(\mathrm{P}<0.01)$. From the results in this study, it was found that combining rice flour with silk fibroin was useful to prepare foam-containing foods.
\end{abstract}

(Received Sep. 21, 1999 ; Accepted Jan. 25, 2000)

絹フィブロインの食品素材化に関する研究は, 平林ら により始められ(1) 3), 絹フィブロインの入ったうどん, 菓子などが商品化されるに至っている4). 絹フィブロイ ンは $\beta$ 構造が多いタンパク質であり ${ }^{5)}$, 濃度, 温度を適 当に選ぶことによってゲル化するととあに，優れた泡沫 特性 ${ }^{6)}$ を有していることが示されている. 一方スポンジ ケーキに関しては品質を高めるための研究が続けられて おり ${ }^{7) \sim 14)}$, また, 小麦粉の一部をグアーガムやポリデキ

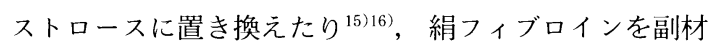
料として用いたスポンジケーキ ${ }^{6)}$ が調製されるに至って いる.しかし，小麦粉を全く用いないスポンジケーキの 調製方法に関する研究はほとんよ゙なされていない，小麦 粉から作られる食品においては，グルテンの役割が重要 である，本研究では，小麦粉中でグルテンが果たしてい る役割を絹フィブロインが果たすように工夫することに よって, 従来小麦粉を用いて作るものとされているスポ
ンジケーキを，小麦粉を用いることなく米粉から作るこ とを目的とした。

\section{実 験 方 法}

\section{1. 試料調製}

(1) 絹フィブロイン溶液の調製

廃絹糸（松岡機業(株), 鶴岡市）を $1 \%$ 炭酸水素ナト リウム中で煮沸洗浄する操作を数回繰り返してセリシン を除去した後, $35 \%$ 塩化カルシウム溶液に移し, $98^{\circ} \mathrm{C}$ で 6 時間加熱溶解させた. この溶液を蒸留水中にて透析 · 脱塩し, 濾過するこよにより絹フィブロイン溶液を得 た. 絹フィブロイン溶液の濃度は $6 \%$ に調整し, 実験に 供した。

(2) スポンジケーキの調製

材料として米粉（タンパク質含量 $6.5 \%$, 灰分含量 $0.3 \%$, 水分含量 $14 \%$ : 中野食品工業(株)), 小麦デンプ

* 山形大学教育学部（干990-8560 山形県山形市小白川町 1-4-12） 
ン（タンパク質含量 $0.2 \%$, 灰分含量 $0.2 \%$, 水分含量 $13.1 \%$ : 和光純薬工業(株)), 薄力粉（タンパク質含量 $8.0 \%$, 灰分含量 $0.4 \%$, 水分含量 14\%：日清製粉(株), ᄀ ラワー), 卵黄, スクロース, 卵白と絹フィブロイン溶液 を用いた.

まず， $6 \%$ 絹フィブロイン溶液 $60 \mathrm{~g}(28.6 \%)$ にスク ロース $12.5 \mathrm{~g}(5.95 \%)$ を加え，ハンドミキサー（M-35, GENERAL ELECTRIC 製) を用いて $950 \mathrm{rpm}$ で覺拌し て絹フィブロイン泡沫を調製した。卵白と絹フィブロイ ン溶液 $30 \mathrm{~g}$ : $30 \mathrm{~g}$, 卵白 $60 \mathrm{~g}$ を用いて同様に卵白/絹 フィブロイン混合泡沫，卵白泡沫を調製した。攪拌時間 については，卵白/絹フィブロイン混合泡沫と卵白泡沫 は最も気泡含量の高い状態の泡沫を用いた。すすおち卵 白/絹フィブロイン混合溶液は攪拌時間 11 分，卵白泡沫 は 8 分とした． 絹フィブロイン泡沫については，気泡含 量の最も高い状態の泡沫を用いると焼成後のスポンジ ケーキ組織内部に空洞が生じるため，流動性のある泡沫 を用い，覺拌時間を 15 分とした。

次に卵黄 $40 \mathrm{~g}$ (19.0\%) とスクロース $12.5 \mathrm{~g}$ (5.95\%) を合わせたものに蒸留水 $35 \mathrm{~g}(16.7 \%)$, 粉 $50 \mathrm{~g}(23.8$ \%), 泡沫 $60 \mathrm{~g}$ を加えて混合し, 含泡生地を調製した。 得られた生地を直径 $15 \mathrm{~cm}$ のシフォンケーキ型に流し 入れ， $170^{\circ} \mathrm{C}$ で 40 分間焼成した。 これを室温にて 2 時間 放冷後, $25^{\circ} \mathrm{C}$ で 24 時間保持し, 測定に供した.

\section{2. 測定方法}

(1) 動的粘弾性

生地の貯蔵弾性率と損失弾性率を，レオログラフーゾ ル (S-IC 型, 東洋精機(株)) を用いて $25^{\circ} \mathrm{C}$ で測定した.

（2）比容積

スポンジケーキのクラムを $2 \mathrm{~cm}$ の立方体に切り, 菜 種置換法 ${ }^{17)}$ により体積を求耻容積 $\left(\mathrm{cm}^{3} / \mathrm{g}\right)$ を算出し た.

\section{(3) 色度}

スポンジケーキの表面の焼き色を色彩色差計 (CR200 ：ミノルタカメラ(株)）を用いて $\mathrm{L}^{*} \mathrm{a}^{*} \mathrm{~b}^{*}$ 值を測定 し，明度，色相，彩度を評価した。

\section{(4) 抵抗応力}

スポンジケーキのクラムを $2 \mathrm{~cm}$ の立方体に切り, 直 径 $4 \mathrm{~cm}$ の円盤形プランジャー（アクリル樹脂製）を用 いて試料の高さの $50 \%$ 圧縮を行い，その抵抗力をク リープメーター（RE-3305，山電(株)）を用い, $25^{\circ} \mathrm{C}$ で 測定した. プランジャーの圧縮速度は $6.0 \mathrm{~cm} / \mathrm{min}$ とし た。

\section{(5) X 線回折}

クラムに 3 倍量の無水エタノールを加え, 乳鉢で摩砕 しながら脱水し，濾過する操作を 3 回繰り返し，アセト ンで洗浄後風乾し，脱水粉末試料を得た18).X 線回折測 定はX 線回折装置（RINT2200，（株）リガク）を使用し， 回折強度により結晶性を測定し，老化速度を調べた。測 定条件は走査範囲 : $2 \theta=4 \sim 40^{\circ}$, 走査速度 $0.5^{\circ} / \mathrm{min}$, 管 電圧 $35 \mathrm{kV}$ ，管電流 $15 \mathrm{~mA}$ とした.

（6）官能検査

米粉を用いたスポンジケーキの嗜好性を評価するた め，評点法により官能検查を行った，薄力粉と卵白泡沫 を用いたスポンジケーキを基準として，米粉と卵白泡 沫, 米粉と卵白/絹フィブロイン混合泡沫, 米粉と絹フィ ブロイン泡沫を用いた 3 種類のスポンジケーキについて 評価した，評価項目は，香り，表面と内部のクラムの色， クラムのきめ, 指で押したときの弾力性, 硬さ, しっと り感，甘さ，総合評価の 9 項目である。 パネル数 (n) は 25 名とした。結果については， $\mathrm{t}$ 検定により有意差を判 定した。

\section{実験結果と考察}

小麦粉は加水混合によってグルテンネットワークを形 成する，絹フィブロインは疎水性であり，粉末化して米 粉と混合した粉体素材に加水しても，ネットワークの形 成は期待できない，また，現存の含泡食品のほとんどは 小麦粉を用いて製造することを前提としており，従来法 が応用できないことが判明した，従って，食品素材の配 合割合のみならず加工プロセスも含めて検討する必要が あった。そこで絹フィブロインを含む泡沫を調製し，こ れに米粉を加えた含泡生地を焼成することによってスポ ンジケーキを調製した。

\section{1. 生地の特性}

各種生地の動的粘弾性の結果を Fig. 1 に示した. 比較 のため粉と混合する前の泡沫の結果も示した．卵白泡沫 では粉を混合することにより，弾性率，粘性率ともに顕 著に低下し，泡沫に絹フィブロインを添加することによ り粘弾性の低下が抑制された。

卵白/絹フィブロイン混合泡沫を用いた生地は単独泡 沫を用いた生地に比べ弾性率，粘性率と屯に大きくな り，泡沫の種類にかかわらず薄力粉より米粉を用いた生 地の方が弾性率が大きくなった。

\section{2. スポンジケーキの特性}

卵白/絹フィブロイン混合泡沫を用い，米粉からスポ ンジケーキを調製することができた。 

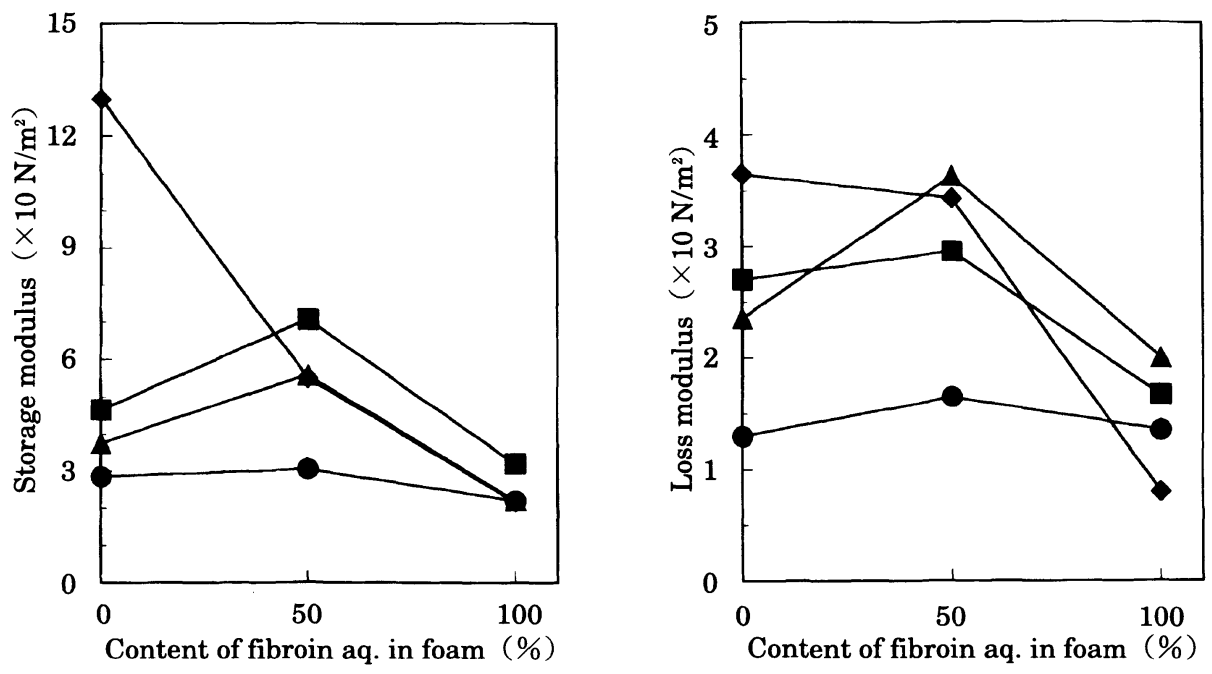

Fig. 1 Dynamic viscoelasticity of the doughs

$\boldsymbol{\square}$, Rice flour ; $\boldsymbol{O}$, Wheat starch ; $\boldsymbol{\Delta}$, Wheat flour ; $\bullet$, Foam

スポンジケーキの断面の写真を Fig. 2 に, また比容積 の結果を Fig. 3 に示した. 写真のスポンジケーキの底辺 はいずれも $4.5 \mathrm{~cm}$ である. 尚, 小麦デンプンと絹フィブ ロイン泡沫を用いたスポンジケーキについては均一に膨 化せず,下部が餅状になった（Fig. 2) ため, 比容積を測 定しなかった。 いずれの試料においても絹フィブロイン の混合割合が増加するに従い膨化が抑えられ, 比容積が 小さくなった。絹繊維の主成分であり， $\beta$ 構造が多い絹

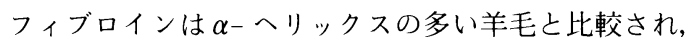
伸展性が低いことが知られている ${ }^{5)}$. 食品中における絹 フィブロインの存在状態の詳細は不明であるが, 絹フィ ブロインの混合割合が増加するに従い比容積が小さく なった結果は, 伸展性が低いという絹フィブロインの夕 ンパク質化学特性の反映したものと考えられた. また米 粉を用いたスポンジケーキは薄力粉を用いたスポンジ ケーキと比べ, 比容積は小さく $2.26 \sim 2.67 \mathrm{~cm}^{3} / \mathrm{g}$ となっ た. 小麦デンプンを用いたスポンジケーキは, 薄力粉を 用いたスポンジケーキと比べて比容積にそれほど違いが 見られなかった。

米粉を用いたスポンジケーキの焼成後の表面の色度の 結果を Table 1 に示した. 卵白/絹フィブロイン混合泡 沫を用いたスポンジケーキは, 最む明度が高くなった. 色相，彩度についても高い値を示した。このことから， 卵白/絹フィブロイン混合泡沫を用いたスポンジヶーキ の焼き色が最も薄いと評価された。

米粉と絹フィブロイン泡沫を用いたスポンジケーキの
圧縮抵抗応力の結果を Fig. 4 に示した. 尚，小麦デンプ ンと絹フィブロイン泡沫を用いたスポンジケーキは, 膨 化が不均一であった（Fig. 2) ため，測定しなかった， ス ポンジケーキの抵抗応力は絹フィブロインを添加するこ とで大きくなり，硬くなることが示された．特に絹フィ ブロイン泡沫を用いたスポンジケーキは抵抗応力が顕著 に大きくなった．また薄力粉より米粉を用いたスポンジ ケーキの方が抵抗応力が大きくなり，硬くなったことが 示された。これは比容積の結果と対応していると考えら れた。

$\mathrm{X}$ 線回折により結晶性を測定し，老化速度を調べた。 Fig. 5 に薄力粉を用いたスポンジケーキの 1 日後の X 線回折図を示した。卵白泡沫を用いたスポンジヶーキで は $17^{\circ}$ 付近に結晶性の回復に伴うピークが出ていること がわかる.しかし絹フィブロイン泡沫を用いたスポンジ ケーキではこのピークは見られなかった．このことから 絹フィブロインを添加することで, 老化速度が遅くなる ことが示された。

米粉を用いたスポンジケーキの嗜好性を評価するた め，官能検査を行った。その結果を Fig. 6 に示した。薄 力粉と卵白泡沫を用いたスポンジケーキの評価值は図の 0 のところに相当する. 米粉と卵白/絹フィブロイン混合 泡沫を用いたスポンジヶーキは, 薄力粉と卵白泡沫を用 いたスポンジケーキと比ベクラムのきめが細かく（P< 0.01), しっとりとしており $(\mathrm{P}<0.01)$ 最もおいしい（P （0.01）と評価された。これらの結果から食品としての 

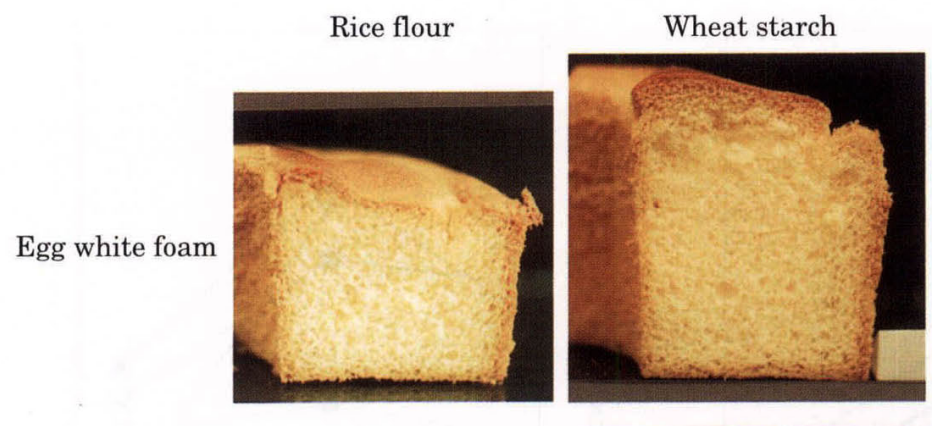

Wheat flour

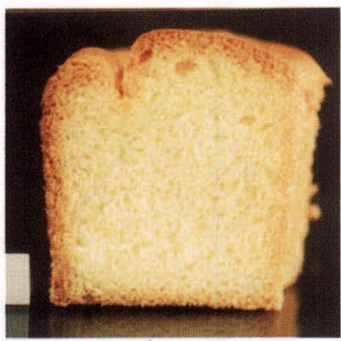

Mixed foam
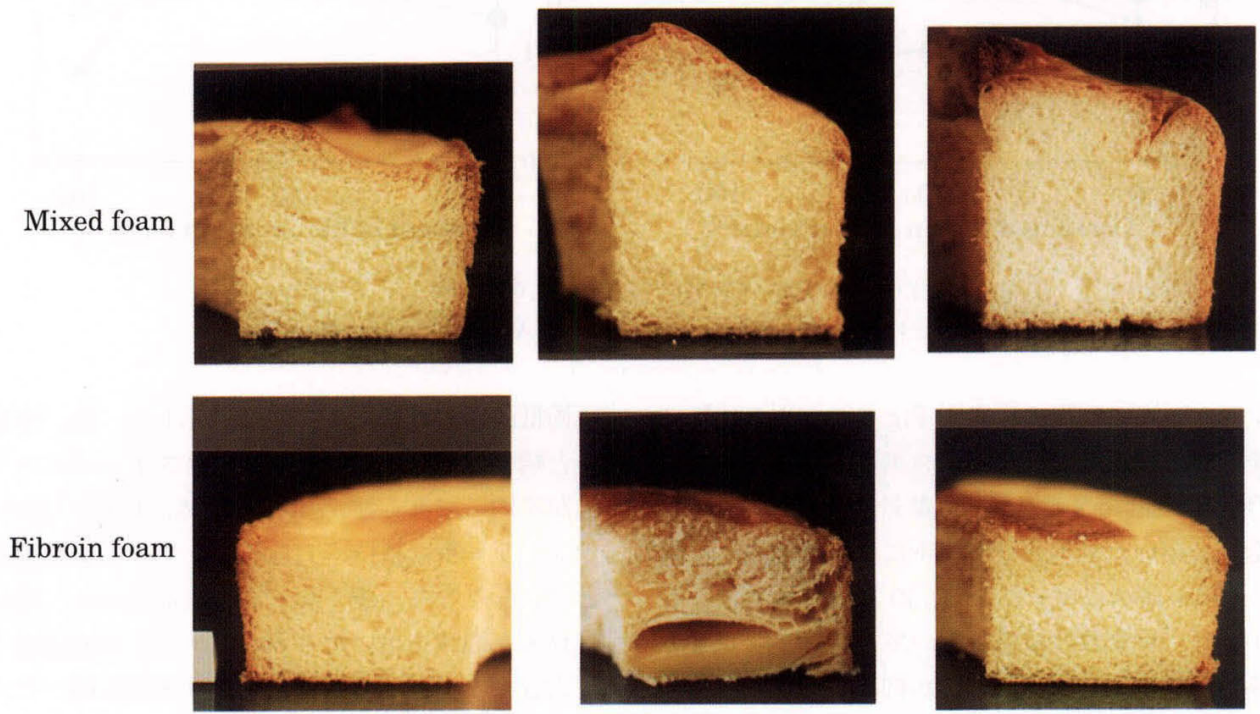

Fig. 2 Cross section images of the sponge cakes

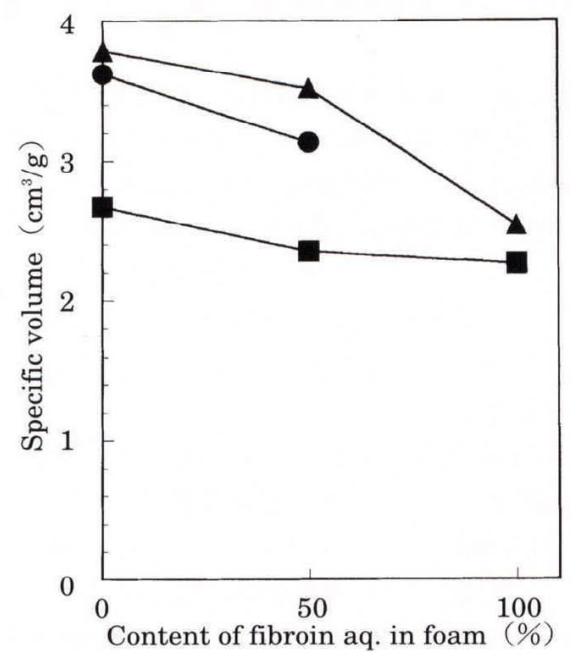

Fig. 3 Specific volume of the sponge cakes

, Rice flour; Wheat starch ;

$\boldsymbol{\Delta}$, Wheat flour
Table 1 Color of the sponge cakes made from rice flour/foam

\begin{tabular}{lrrc}
\hline \hline & \multicolumn{3}{c}{ Rice flour } \\
\cline { 2 - 4 } & $\begin{array}{c}\text { Egg white } \\
\text { foam }\end{array}$ & $\begin{array}{c}\text { Mixed } \\
\text { foam }\end{array}$ & $\begin{array}{c}\text { Fibroin } \\
\text { foam }\end{array}$ \\
\hline $\mathrm{L}$ (Lightness) & 53.0 & 55.2 & 50.2 \\
$\mathrm{~b} / \mathrm{a}$ (Hue) & 1.8 & 2.1 & 1.6 \\
$\sqrt{\mathrm{a}^{2}+\mathrm{b}^{2}}$ (Chroma) & 36.2 & 36.9 & 32.1 \\
\hline
\end{tabular}

受諾性についてむ問題ないと考えられた.

絹フィブロインは絹織物産業における残糸から精製す るため，これを食品素材として利用することは原材料費 が安価であるばかりでなく資源循環の観点からも「地球 環境にやさしい」と言うことができる.さらに肝機能の 維持や血中コレステロール低下作用などの生体調節機 
能 ${ }^{19)}$ 21) あ期待される。このように，本研究で検討した 「絹フィブロインと米粉の複合化」のコンセプトは, 環境 保全之食品機能, おいしさの3つの観点からの要請を満 たすものである，本研究によって得られた成果は，外国 産に比べて品質が劣るとされる国産小麦を用いた系にも 適用可能亡考えられる.

要 約

本研究では, ゲル化能を有する絹フィブロインに着目 し，これを米粉と複合化してスポンジケーキの調製を試

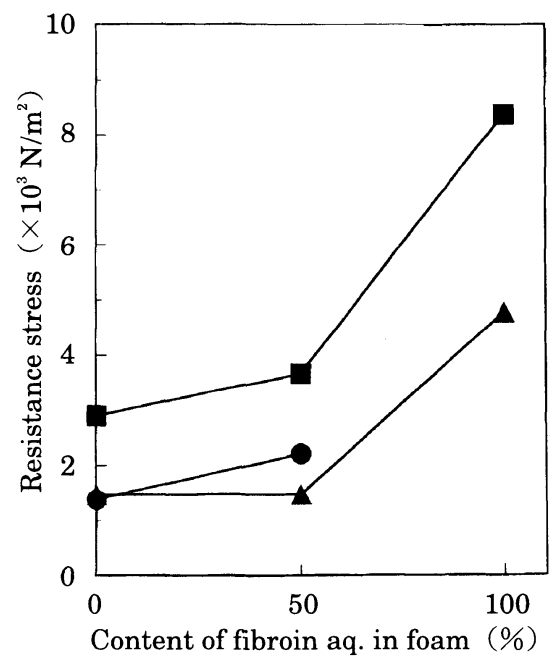

Fig. 4 Resistance stress of the sponge cakes

, Rice flour ;, Wheat starch ;

$\boldsymbol{\Delta}$, Wheat flour

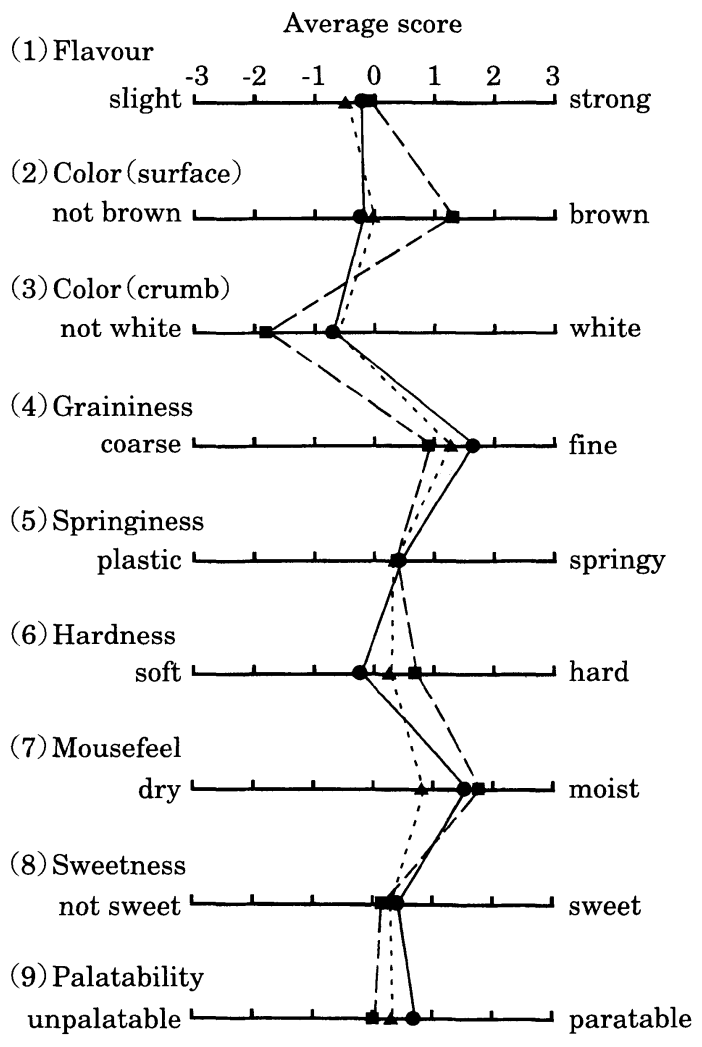

Fig. 6 Results of sensory evaluation of the sponge cakes made from rice flour/ foam

$\boldsymbol{\Delta}$, rice flour/egg white foam; $\boldsymbol{0}$, rice flour/ mixed foam ; $\mathbf{\square}$, rice flour/fibroin foam

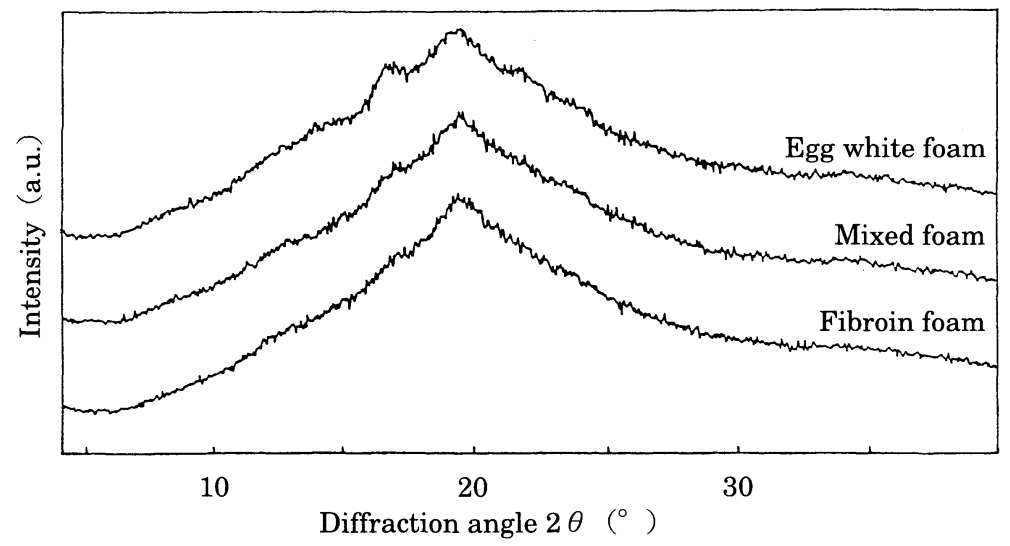

Fig. $5 \mathrm{X}$-ray diffraction curves of the sponge cakes made from wheat flour/foam (stored for one day) 
み，複合化効果について検討した。

1. 薄力小麦粉を用いることなく, 米粉と絹フィブロ インを複合化させることにより，スポンジケーキを調製 することができた.

2. 米粉上絹フィブロイン泡沫を用いたスポンジケー キは薄力粉上卵白泡沫を用いたスポンジケーキと比べ, 比容積が低くなり, 膨化が小さかった。

3. 絹フィブロインを添加することでスポンジケーキ の老化速度が遅くなった。

4. 官能検查の結果より，米粉と卵白/絹フィブロイ ン混合泡沫を用いたスポンジケーキは薄力粉と卵白泡沫 を用いたスポンジケーキと比べ, 内部のきめが細かく $(\mathrm{P}<0.01)$, しっとりとしており $(\mathrm{P}<0.01)$, 最むおいし い（P<0.01）と評価された.

本研究の一部は, (財)飯島記念食品科学振興財団の援 助で行われたものであり，同財団に感謝いたします。ま た絹糸を供与していただきました鶴岡市松岡機業(株) に御礼申し上げます。

\section{文献}

1）平林 潔 - 渡辺 誠・鈴木 誠: 繊維学会誌, 45, 263 (1989).

2) 平林 潔：バイオインダストリー, 6, 749 (1989).

3）平林 潔: 月刊フードケミカル， 1，41（1990).

4）平林 潔:「シルクを食べる」, 高輪出版社, p. 14 (1996).

5）濱口浩三 : 「改訂蛋白質機能の分子論」, 学会出版 センター, p. 31 (1990).

6）平尾和子・ 木村由里子・五十嵐喜治 : 食科工誌,
45, 692 (1998).

7) Peleg, M., Roy, I., Campanella, O.H. and Normand, M.D. : J. Food Sci., 54, 947 (1989).

8) Attenburrow, G.E., Goodband, R.M., Taylor, L.J. and Lillford, P.J. : J. Cereal Sci., 9, 61 (1989).

9) Sievert, D., Pomeranz, Y. and Abdelrahman, A. : Cereal Chem., 67, 10 (1990).

10) Guinot, P. and Mathlouthi, M. : J. Sci. Food Agric., 54, 413 (1991).

11) Czuchajowska, Z., Paszczynska, B. and Pomeranz, Y. : Cereal Chem., 69, 516 (1992).

12) Takeda, K. : Cereal Chem., 71, 6 (1994).

13) Sreenath, H.K., Sudarshanakrishna, K.R., Prasad, N.N. and Santhanam, K. : Starch, 48, 72 (1996).

14) Grau, H., Wehrle, K. and Arendt, E.K. : Cereal Chem., 76, 303 (1999).

15) Dogra, R., Hill, M.A. and Strange, R. : Food Hydrocolloids, 3, 1 (1989).

16) Attia, E.S.A., Shehata, H.A. and Askar, A. : Food Chemistry, 48, 169 (1993).

17) Griswoft, R.N. : The Experimental Study of Foods, Houthoun Miffin, Boston, p. 525 (1962).

18）三好恵真子 - 条野恵子 - 大久保昌子 - 高橋雅江 中濱信子: 澌粉科学, 39, 253 (1992).

19）平林 潔・陳開利・勢籏毅：New Food Industry, 33, 1 (1991).

20）平林 潔: 化学, 47, 530 (1992).

21）平林 潔 - 平岩陽一: New Food Industry, 35, 17 (1993).

(平成 11 年 9 月 21 日受付, 平成 12 年 1 月 25 日受理) 